\title{
Effect of dietary supplementation with propolis and Aloe barbadensis extracts on hematological parameters and parasitism in Nile tilapia
}

\author{
Efeito da suplementação dietária com extratos de própolis e Aloe barbadensis sobre \\ parâmetros hematológicos e parasitismo em tilápia do Nilo
}

Geovana Dotta ${ }^{1}$; Aline Brum ${ }^{1}$; Gabriela Tomas Jeronimo'; Marcelo Maraschin²; Maurício Laterça Martins ${ }^{1 *}$

\begin{abstract}
${ }^{1}$ Laboratório AQUOS-Sanidade de Organismos Aquáticos, Departamento de Aquicultura, Centro de Ciências Agrárias - CCA, Universidade Federal de Santa Catarina - UFSC, Florianópolis, SC, Brasil

${ }^{2}$ Laboratório de Morfogênese e Bioquímica Vegetal, Departamento de Fitotecnia, Centro de Ciências Agrárias - CCA, Universidade Federal de Santa Catarina - UFSC, Florianópolis, SC, Brasil
\end{abstract}

Received December 5, 2014

Accepted December 8, 2014

\begin{abstract}
This study evaluated the influence of diet supplementation with propolis and Aloe barbadensis on hematological parameters and parasitism in tilapia. One hundred and eighty fish were distributed among 12 water tanks forming four treatments: fish supplemented with a 1:1 mixture of $0 \%, 0.5 \%, 1 \%$ and $2 \%$ propolis and aloe extracts. After the fish had been fed on the experimental diets for 15 and 21 days, blood samples were taken and parasites collected. The monogeneans Cichlidogyrus sclerosus, C. halli, C. thurstonae and Scutogyrus longicornis were identified in the gills. Between the sampling times, there were increases in the numbers of erythrocytes, leukocytes, thrombocytes and lymphocytes, as observed after 21 days, possibly due to the stress level over the course of the assay and/or accumulation of substances in the organism. Supplementation with the mixture of propolis and aloe for 15 days showed the highest efficacy against the parasites. This was possibly due to the association between the two compounds. The results demonstrated that supplementation with mixtures of extracts did not produce hematological alterations and also favored a significant reduction in the number of gill parasites. The best results were achieved after 15 days of feeding with a diet with $0.5 \%$ and $1 \%$ supplementation with the extract mixture, which increased efficiency by 83 and $85 \%$ respectively
\end{abstract}

Keywords: Hematology, parasitology, propolis, Aloe barbadensis.

\section{Resumo}

Este estudo avaliou a influência da alimentaçáo de tilápias com dieta suplementada com extratos de própolis e Aloe barbadensis sobre os parâmetros hematológicos e parasitismo. Setenta e dois peixes foram distribuídos em 12 tanques, formando 4 tratamentos: peixes suplementados na dieta com extrato de própolis e aloe ( $0 \%, 0,5 \%, 1 \%$ e $2 \%)$. Após 15 e 21 dias de alimentação com dietas experimentais foram realizadas coletas de sangue e parasitos. Os monogeneas Cichlidogyrus sclerosus, C. halli, C. thurstonae e Scutogyrus longicornis foram identificados nas brânquias. Entre os períodos de coleta, observou-se aumento nos valores de eritrócitos, leucócitos, trombócitos e linfócitos, após 21 dias de alimentaçáo, o que pode significar estresse ao longo do período experimental e/ou acúmulo dos produtos no organismo.A suplementação com a mistura de própolis e aloe, por 15 dias, apresentou melhor eficácia frente parasitos, possivelmente, devido à associação dos compostos. Os resultados demonstram que a suplementação com a mistura dos extratos não alterou os parâmetros hematológicos, além de favorecer redução significativa no número de parasitos branquiais. Os melhores resultados foram obtidos em 15 dias de alimentaçáo com a dieta suplementada com $0,5 \%$ e $1 \%$ da mistura dos extratos, respectivamente por $83 \%$ e $85 \%$ de eficiência.

Palavras-chave: Hematologia, parasitologia, própolis, Aloe barbadenensis.

\footnotetext{
*Corresponding author: Maurício Laterça Martins, Laboratório AQUOSSanidade de Organismos Aquáticos, Departamento de Aquicultura, Centro de Ciências Agrárias - CCA, Universidade Federal de Santa Catarina - UFSC, Rod. Ademar Gonzaga, 1346, CEP 88040-900, Florianópolis, SC, Brasil, e-mail: mlaterca@cca.ufsc.br
} 


\section{Introduction}

According to the Brazilian Health Surveillance Agency (ANVISA, 2003), phytotherapeutics are medicines derived from medicinal plants that comprise plant-derived drugs alone (in the form of extracts, tinctures, oils, waxes, exudates, juices and other presentations). Within aquaculture, these medicines have been gaining ground because they have several advantages in fish farms, such as lower environmental impact because they are biodegradable products, lower chemical waste in animals and potential for lower toxicity, because they are less concentrated. Moreover, they have different mechanisms of action, which means greater resistance and lower cultivation costs (COIMBRA et al., 2006).

Several herbal medicines can be used for treating fish parasites. Among these, nin (CRUZ et al., 2004) and garlic (MARTINS et al., 2004) can be administered either as therapeutic baths or as dietary supplements. Aloe barbadensis Miller, which belongs to the Asphodelaceae family and is commonly known as the aloe plant, can also be used (WICHTL, 2004). The aloe plant is widely used in popular medicine due to its beneficial effects, such as in relation to treating burns, hepatitis and diabetes and controlling blood lipid levels (OKYAR et al., 2001), and as a healing agent (PAEZ et al., 2000), antiulcerative agent, antineoplastic agent (SAKAI, 1989; KOBAYASHI et al., 1993; MAEDA et al., 1998) and antiviral agent (KIM et al., 1999). Chemical compounds of parenchymal substances and aloe extract are responsible for their immunostimulant and healing properties (IMANISHI, 1993).

Another herbal product option is propolis, a substance of plant and animal origin derived from resinous gummy and balsamic substances that is collected by bees from flower buds and plant exudates and modified in the hive through addition of salivary secretions and wax (PINHEIRO-FILHO, 1998). Propolis is used by bees to protect the hive against attack by other insects and proliferation of microorganisms, including fungi and bacteria (GHISALBERTI, 1979; MARCUCCI, 1995). It has been demonstrated to be effective against Gram-positive bacteria and fungi, and can act as an immunostimulant (ORSI et al., 2005). The improvement in performance observed among animals treated with diets supplemented with propolis extract may be a consequence of the improvement in immune response, allied with the efficacy of its heterogeneous composition (MATSUNO, 1992). Great numbers of biological and chemical studies on propolis published during the last decade have demonstrated that flavonoids predominate in the composition of propolis. According to Marcucci (1995), more than 50 flavonoids have been discovered, including compounds belonging to the vegetable polyphenol, aromatic acid and oleic acid groups. In aquaculture, the action of these herbal medicines can be exploited mainly through stimulation of immune responses and treatment of parasitic infestation.

Parasitism occurs as a result of an interaction between host, parasite and environment (BUCHMANN \& LINDENSTRØM, 2002). Some factors or substances are responsible for lowering the host immune response, thereby resulting in unbalanced host/parasite/environment interaction. Such factors include water temperature, stress level (XU et al., 2012), nutritional quality (CAVICHIOLO et al., 2002), age and natural immunity
(BUCHMANN \& LINDENSTRØM, 2002). In intensive farming systems, high fish density, low water flow and high organic matter concentration contribute towards the growth and reproduction of parasites (MORAES \& MARTINS, 2004).

Monogenean ectoparasites of fish are characterized by the presence of sclerotized anchoring structures, and these parasites are preferentially located in the gills, nostrils, eyes and body surface. This feature enhances pathogenicity by causing tissue injury and behavior changes, with increased mucus production, skin hemorrhage, gill filament hyperplasia, anorexia and fish death (PAVANELLI et al., 2008). Moreover, in cases of less severe infection, the lesions produced serve as small doors that are open to secondary infections (MARTINS \& ROMERO, 1996).

The present study was designed to test the efficacy of different concentrations of propolis and aloe extracts in supplements to the diet of tilapia, as immunomodulators of the primary immune response and thus as possible regulators of parasite infestation.

\section{Material and Methods}

\section{Experimental conditions}

A total of 180 juvenile Nile tilapias (mean weight: $18.13 \pm 5.7 \mathrm{~g}$; and mean total length: $9.94 \pm 1.14 \mathrm{~cm}$ ) from the same spawning at the Panamá fish farm, in Paulo Lopes, SC, Brazil, were acclimatized for seven days before assaying. After this period, the fish were distributed into 30 tanks of capacity $100 \mathrm{~L}$ of capacity with constant aeration, biological filtration and water quality maintained at $\mathrm{pH} 6.0 \pm 1.5$ (Alfakit, AT-350), temperature $24.0 \pm 2.8^{\circ} \mathrm{C}$, ammonia $0.08 \pm 0.33 \mathrm{mg} / \mathrm{L}$ (Alfakit, colorimetric method) and dissolved oxygen $6.0 \pm 0.0 \mathrm{mg} / \mathrm{L}$ (Hanna, HI 9146). The experiment comprised a completely randomized factorial design divided into 12 treatments with three replicates each (nine fish/treatment) and one control group, as follows: fish supplemented with propolis extract $(0.5 \%, 1 \%$ and $2 \%)$; fish supplemented with aloe extract $(0.5 \%, 1 \%$ and $2 \%)$; fish supplemented with 1:1 mixtures of propolis and aloe extracts $(0.5 \%, 1 \%$ and $2 \%)$; and non-supplemented fish. After 15 and 20 days of feeding with experimental diets, blood samples were taken for parasite quantification.

\section{Preparing the supplemented diet}

We used commercial feed $\left(\right.$ Nicoluzzi $\left.^{\circledR}\right)$ containing $28 \%$ crude protein, to which was added solutions of hydroalcoholic extract of propolis, aqueous extract of aloe or a mixture in the proportions of $1: 1$, to obtain final concentrations of $0.5 ; 1$ and $2 \%$ of the total quantity of feed offered per day.

\section{Hematological analysis}

After the fish had been anesthetized in clove oil $\left(75 \mathrm{mg} . \mathrm{L}^{-1}\right)$, blood samples were collected from the caudal vein using a syringe containing a drop of 10\% EDTA solution (Ethics Committee no. 23080.009240/2011-93/CEUA/UFSC), in order to measure hematocrit (GOLDENFARB et al., 1971), red blood cell count in a Neubauer chamber, white blood cell count and thrombocyte 
count (DOTTA et al., 2011). To obtain a differential leukocyte count, blood smears were stained with a combination of Giemsa/ May-Grünwald (ROSENFELD, 1947), in which a hundred cells were counted to determine the cell percentage.

\section{Parasitological analysis}

After blood collection, the fish were sacrificed for parasitological examination and gross pathological examination in accordance with Ghiraldelli et al. (2006) to check the influence of treatments on the parasite fauna. Prevalence, mean intensity and abundance data were obtained in accordance with Bush et al. (1997). Using these data, the efficacy was determined using the formula: $\mathrm{E}$ = MNPCG- MNPTG x 100/MNPCG (E: efficacy; MNPCG: mean number of parasites in control group; and MNPGT: mean number of parasites in treated group). The number of monogeneans in the gills was quantified as described by Ghiraldelli et al. (2006) and they were identified as described by Paperna \& Thurston (1969), Ergens (1981), Douëllou (1993) and Pariselle \& Euzet (1995).

\section{Statistical analysis}

The data were subjected to factorial analysis of variance (ANOVA) using Statsoft's STATISTICA 7.0. The Bartlett test was used to ascertain the homoscedasticity, while the Tukey test was used to compare the means. Data transformations were used according to pertinence.

\section{Results}

There were statistically significant increases in the hematocrit and in the red blood cell (RBC), white blood cell (WBC), thrombocyte and lymphocyte counts between the blood samples collected after 15 days and 21 days of feeding with the unsupplemented diet (Table 1). The experimental diet with $0.5 \%$ showed significant increase in all the hematological parameters studied after 21 days, except for red blood cells (RBC). On the other hand, there was no significant difference among the treatments over the same period. The experimental diet with $1 \%$ showed significant increase in white blood cells (WBC), lymphocytes and neutrophils after 21 days of feeding, while the highest monocyte counts among extract concentrations for this diet were shown after 15 days of feeding and remained at high values over the second data collection period. Fish supplemented with $2 \%$ did not show any significant difference between the feeding periods (Table 1).

The parasitological analysis revealed the presence of Cichlidogyrus sclerosus, C. halli Price and Kirk, 1967, C. thurstonae Ergens, 1981 and Scutogyrus longicornis Paperna and Thurston, 1969 (Monogenoidea: Dactylogyridae) on the gills of the tilapias examined. Table 2 shows that unsupplemented fish (0\%) presented a significant increase in the mean intensity of parasites on the gills and that this difference continued until 21 days of feeding, with different concentrations of mixed extracts. One hundred percent prevalence was also found in un-supplemented fish (Table 2). The mean abundance of monogeneans was lower in the fish supplemented with the extracts, at both collection times (Figures 1, 2 and 3).

\section{Discussion}

This study demonstrates the need for and importance of knowledge regarding use of alternative products for maintenance of homeostasis and fish welfare, as well as activity against parasites shown by plant extracts. In this assay, the hematological variables did not show any variation between the different

Table 1. Hematological parameters of Nile tilapia fed supplemented diet with a mixture of propolis and Aloe barbadensis at concentrations of $0 \%, 0.5 \%, 1 \%$ and $2 \%$ for 15 and 21 days. Lowercase letters indicate significant differences among the concentrations of each extract and uppercase letters indicate significant differences between the different collection days for each concentration of the extract $(\mathrm{p}<0.05)$ by Tukey test.

\begin{tabular}{|c|c|c|c|c|}
\hline \multirow{2}{*}{ Parameters } & \multicolumn{4}{|c|}{15 feeding days } \\
\hline & $\mathbf{0} \%$ & $0.5 \%$ & $1 \%$ & $2 \%$ \\
\hline Hematocrit (\%) & $31.2 \pm 4.9^{\mathrm{aA}}$ & $28.2 \pm 2.6^{\mathrm{aA}}$ & $29.7 \pm 2.3^{\mathrm{aA}}$ & $27.3 \pm 2.8^{\mathrm{aA}}$ \\
\hline $\operatorname{RBC}\left(x 10^{6} \cdot \mu l^{-1}\right)$ & $1.58 \pm 0.41^{\mathrm{aA}}$ & $1.43 \pm 0.31^{\mathrm{aA}}$ & $1.65 \pm 0.46^{\mathrm{aA}}$ & $1.71 \pm 0.48^{\mathrm{aA}}$ \\
\hline $\mathrm{WBC}\left(\mathrm{x} 10^{3} \cdot \mu \mathrm{l}^{-1}\right)$ & $54.4 \pm 19.5^{\mathrm{aA}}$ & $35.8 \pm 9.7^{\mathrm{aA}}$ & $45.3 \pm 22.7^{\mathrm{aA}}$ & $52.8 \pm 19.5^{\mathrm{aA}}$ \\
\hline Thrombocytes $\left(\mathrm{x} 10^{3} \cdot \mu \mathrm{l}^{-1}\right)$ & $22.9 \pm 12^{\mathrm{aA}}$ & $24.8 \pm 13.3^{\mathrm{aA}}$ & $19.1 \pm 11.1^{\mathrm{aA}}$ & $25.5 \pm 17.7^{\mathrm{aA}}$ \\
\hline Lymphocytes $\left(\mathrm{x} 10^{3} \cdot \mu^{-1}\right)$ & $44.1 \pm 17.1^{\mathrm{aA}}$ & $30.5 \pm 8.3^{\mathrm{aA}}$ & $36.4 \pm 22.4^{\mathrm{aA}}$ & $45.1 \pm 18.4^{\mathrm{aA}}$ \\
\hline Neutrophils $\left(\mathrm{x} 10^{3} \cdot \mu \mathrm{l}^{-1}\right)$ & $6.5 \pm 7.3^{\mathrm{aB}}$ & $3.7 \pm 2.8^{\mathrm{aA}}$ & $3.8 \pm 2.6^{\mathrm{aA}}$ & $4.4 \pm 3.7^{\mathrm{aA}}$ \\
\hline Monocytes $\left(\mathrm{x} 10^{3} \cdot \mu \mathrm{l}^{-1}\right)$ & $4.1 \pm 4.8^{\mathrm{bA}}$ & $1.5 \pm 0.5^{\mathrm{aA}}$ & $4.9 \pm 5.1^{\mathrm{bA}}$ & $3.3 \pm 1.5^{\mathrm{abA}}$ \\
\hline \multirow{2}{*}{ Parameters } & \multicolumn{4}{|c|}{21 feeding days } \\
\hline & $\mathbf{0} \%$ & $0.5 \%$ & $1 \%$ & $2 \%$ \\
\hline Hematocrit (\%) & $34.9 \pm 7.2^{2 \mathrm{~B}}$ & $30.9 \pm 8.18^{\mathrm{aB}}$ & $28.38 \pm 4.83^{\mathrm{aA}}$ & $29.3 \pm 6.5^{\text {aA }}$ \\
\hline $\mathrm{RBC}\left(\mathrm{x} 10^{6} \cdot \mu \mathrm{l}^{-1}\right)$ & $3.43 \pm 0.86^{\mathrm{aB}}$ & $2.14 \pm 1.13^{\mathrm{aA}}$ & $2.46 \pm 1.27^{\mathrm{aA}}$ & $2.01 \pm 0.84^{\mathrm{aA}}$ \\
\hline WBC $\left(\mathrm{x} 10^{3} \cdot \mu \mathrm{l}^{-1}\right)$ & $88.43 \pm 22.42^{\mathrm{bB}}$ & $64.62 \pm 40.81^{\mathrm{aB}}$ & $68.13 \pm 41.57^{\mathrm{aB}}$ & $53.37 \pm 32.30^{\mathrm{aA}}$ \\
\hline Thrombocytes $\left(\mathrm{x} 10^{3} \cdot \mu^{-1}\right)$ & $38.17 \pm 9.62^{\mathrm{bB}}$ & $20.31 \pm 26.80^{\mathrm{aA}}$ & $17.98 \pm 11.05^{\mathrm{aA}}$ & $21.94 \pm 13.50^{\mathrm{aA}}$ \\
\hline Lymphocytes $\left(\mathrm{x} 10^{3} \cdot \mu \mathrm{l}^{-1}\right)$ & $80.51 \pm 38.62^{\mathrm{bB}}$ & $49.63 \pm 36.70^{\mathrm{aB}}$ & $55.24 \pm 34.45^{\mathrm{aB}}$ & $45.96 \pm 29.80^{\mathrm{aA}}$ \\
\hline Neutrophils $\left(\mathrm{x} 10^{3} \cdot \mu \mathrm{l}^{-1}\right)$ & $4.0 \pm 1.8^{\mathrm{aA}}$ & $10.86 \pm 4.7^{\mathrm{bB}}$ & $7.8 \pm 4.4^{\mathrm{abB}}$ & $4.2 \pm 2.5^{\mathrm{aA}}$ \\
\hline Monocytes $\left(\mathrm{x} 10^{3} \cdot \mu \mathrm{l}^{-1}\right)$ & $3.8 \pm 3.4^{\mathrm{aA}}$ & $4.1 \pm 4.0^{\mathrm{aB}}$ & $4.7 \pm 4.3^{\mathrm{aA}}$ & $3.1 \pm 2.3^{\mathrm{aA}}$ \\
\hline
\end{tabular}


Table 2. Mean values of prevalence and mean intensity of parasites in the gills of Nile tilapia fed supplemented diet with a mixture of propolis and Aloe barbadenis (P:A) at concentrations of 0\%, 0.5\%, 1\% and 2\% for 15 and 21 days. Lowercase letters indicate significant differences among the concentrations of extract and uppercase letters indicate significant differences between the different collection days for each concentration of the extract $(\mathrm{p}<0.05)$ by Tukey test.

\begin{tabular}{|c|c|c|c|c|c|}
\hline \multicolumn{2}{|c|}{ Concentrations } & \multicolumn{2}{|c|}{15 days } & \multicolumn{2}{|c|}{21 days } \\
\hline & & \multirow{2}{*}{$\begin{array}{c}\text { Prevalence }(\%) \\
100\end{array}$} & \multirow{2}{*}{$\begin{array}{r}\text { Mean intensity } \\
10.56 \pm 11.39^{\mathrm{bA}}\end{array}$} & \multirow{2}{*}{$\begin{array}{c}\text { Prevalence }(\%) \\
100\end{array}$} & \multirow{2}{*}{$\begin{array}{c}\text { Mean intensity } \\
6.89 \pm 4.46^{\mathrm{bA}}\end{array}$} \\
\hline P:A & $0 \%$ & & & & \\
\hline$P: A$ & $0.5 \%$ & 89 & $2.25 \pm 2.00^{\mathrm{aA}}$ & 89 & $2.38 \pm 2.11^{\mathrm{aA}}$ \\
\hline P:A & $1 \%$ & 66 & $2.67 \pm 1.77^{\mathrm{aA}}$ & 89 & $3.88 \pm 3.44^{\mathrm{aA}}$ \\
\hline P:A & $2 \%$ & 78 & $3.14 \pm 2.44^{\mathrm{aA}}$ & 66 & $1.83 \pm 1.22^{\mathrm{aA}}$ \\
\hline
\end{tabular}

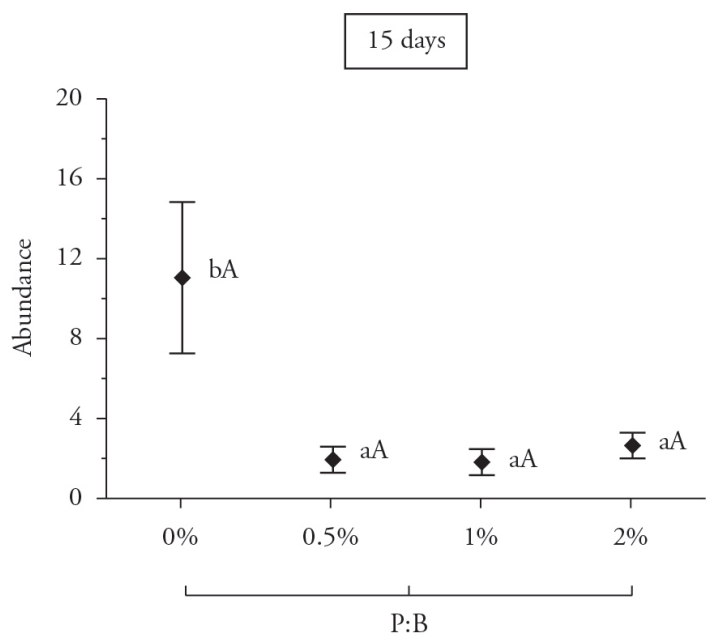

Figure 1. Abundance of parasites in the gills of Nile tilapia fed supplemented diet with mixture of propolis and Aloe barbadensis extracts (P:A) at concentrations of $0 \%, 0.5 \%, 1 \%, 2 \%$ for 15 days. Lowercase letters indicate significant differences among the concentrations of each extract and uppercase letters indicate significant differences between the different collection days for each concentration of the extract $(\mathrm{p}<0.05)$ by Tukey test.

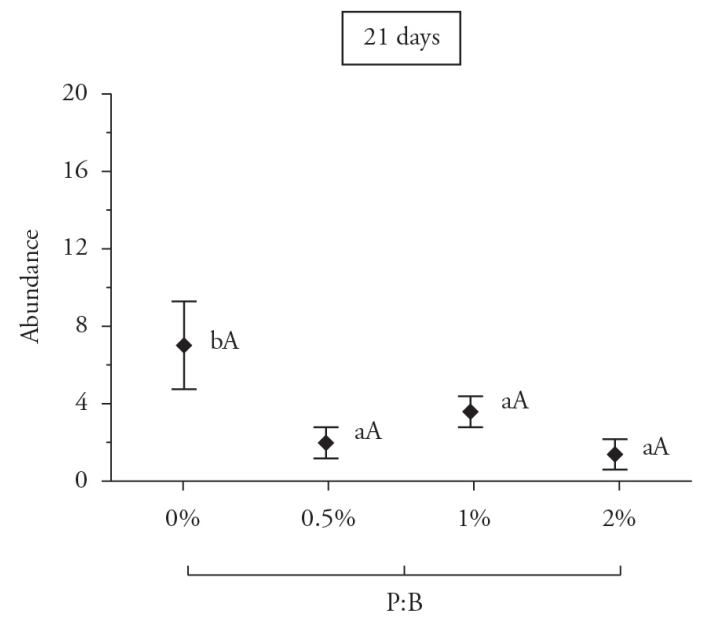

Figure 2. Abundance of parasites in the gills of Nile tilapia fed supplemented diet with mixture of propolis and Aloe barbadensis extracts (P:A) at concentrations of $0 \%, 0.5 \%, 1 \%, 2 \%$ for 21 days. Lowercase letters indicate significant differences among the concentrations of each extract and uppercase letters indicate significant differences between the different collection days for each concentration of the extract $(\mathrm{p}<0.05)$ by Tukey test.

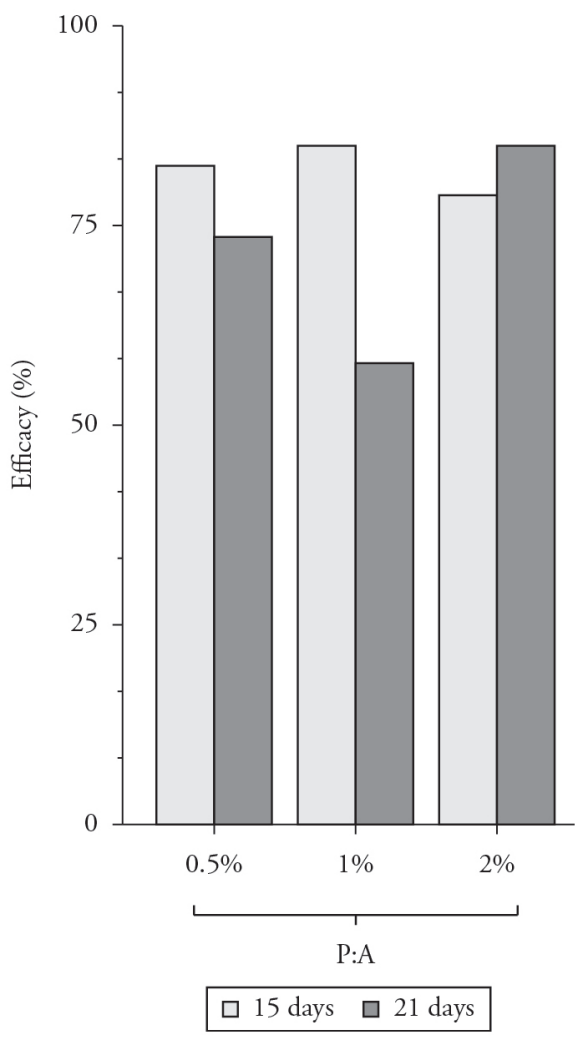

Figure 3. Efficacy of the mixture of propolis and Aloe barbandensis (P:A) at concentrations of $0 \%, 0.5 \%, 1 \%, 2 \%$ supplemented in the diet of Nile tilapia parasitized by Cichlidogyrus sclerosus, Cichlidogyrus halli, Cichlidogyrus thurstonae and Scutogyrus longicornis for 15 and 21 days.

concentrations of the extracts in the diet. Hematological analysis on fish is a tool of fundamental importance for biological and biochemical knowledge of normal and pathological conditions (FUJIMOTO et al., 2012). Hematological changes in the levels of erythrocytes, leukocytes, thrombocytes and lymphocytes were observed after 21 days of treatment in the groups supplemented with $0.5 \%$ and $1 \%$, possibly caused by the stress of confinement under the experimental conditions. This was also observed among the unsupplemented fish. According to Ranzani-Paiva \& SilvaSouza (2004), changes in the hematological parameters of fish can be observed when they are infected or subjected to stress, or when their food is changed. 
Supplementation with the mixture of propolis and Aloe vera extracts showed excellent efficacy outcomes in this study. Studies on mammals have demonstrated that propolis presents effective action against Trypanosoma, a pathogenic microorganism that causes human and animal diseases (SALOMÃO et al. 2004). Ayres et al. (2007) reported that, in vitro, there was a decrease in Leishmania amazonensis infection after propolis administration. Oda et al. (2011) explained that the mechanisms through which propolis extracts exert their leishmanicidal effect in vivo are unclear, but activation of macrophages has been suggested as a mechanism. Macrophages are involved in functions such as phagocytosis, enzyme release, generation of free radicals and mediation of inflammatory processes. It has been suggested that propolis may act towards production of microbicidal substances by macrophages (ORSI et al., 2000), through stimulating the response or decreasing the diameter of the lesions caused by the presence of parasites in the tissues of the host organism (ODA et al., 2011).

The good results achieved with regard to combating monogeneans in this study can be attributed to the combination of aloe and propolis. Stevens (1999) stressed that the resin located in the channels below the epidermis of the leaves of $A$. barbadensis presents anthraquinones (aloin and emodin), which are substances with cathartic and laxative activity in animals and humans (STEVENS, 1999). These compounds may cause damage to the intestinal epithelium if used as supplements for long periods or at high concentrations. Nevertheless, the antifungal, antiinflammatory, hypoglycemic, hemagglutination and mitogenic activity towards lymphocytes remains the main feature of interest in studying this product (CHOI \& CHUNG, 2003; TAININ CHOW et al., 2005; MURAKAMI et al., 2009). Several polysaccharides have been detected and isolated from the pulp of aloe, including mannose, galactose, arabinose, glucuronic acid and pectic acid (NI et al., 2004). Other polysaccharides present in the gel of $A$. barbadensis include glucomannan and acemannan. According to Vega et al. (2005), acemannan is a substance that acts by increasing the strength of the immune system of the organism against parasites, bacteria and viruses.

Supplementation with the mixture of propolis and $A$. barbadensis for 15 days showed the best efficacy against parasites. The combination of these two compounds provided in the diet for 21 days, negatively influenced the results from the present study, possibly due to stress containment and/or accumulation of the products. However, it is known that one of the main factors that influence fish health is dietary balance, such that a combination of compounds is needed in order to meet the appropriate nutritional requirements. Dietary supplements can also stimulate the action of nonspecific defense mechanisms and immune responses in fish.

The results demonstrated that supplementation with mixtures of the extracts did not show any alterations in the hematological parameters and, moreover, this favored significant reduction in the number of gill parasites. The best results were achieved after 15 days of feeding with diet supplemented with $0.5 \%$ and $1 \%$ of the mixture of extracts, which respectively presented 83 and $85 \%$ efficacy.

\section{Acknowledgements}

The authors thank CNPq (National Council for Scientific and Technological Development, Brazil) for financial support and Grant to M.L. Martins (302493/2010-7); to REUNI program (Restructuring and Expansion of Federal Universities) for Doctoral scholarship to G. Dotta; to Nicoluzzi Rations Ltda, for ration during the experiment.

\section{References}

Agência Nacional de Vigilância Sanitária - ANVISA. Medicamentos fitoterápicos. Epi Info [online]. 2003 [cited 2013 July 10]. Available from: http://www.anvisa.gov.br

Ayres DC, Marcucci MC, Giorgio S. Effects of Brazilian propolis on Leishmania amazonensis. Mem Inst Oswaldo Cruz 2007; 102(2): 215-220. http://dx.doi.org/10.1590/S0074-02762007005000020. PMid: 17426888

Buchmann K, Lindenstrøm T. Interactions between monogenean parasites and their fish hosts. Int J Parasitol 2002; 32(3): 309-319. http:// dx.doi.org/10.1016/S0020-7519(01)00332-0. PMid:11835971

Bush AO, Lafferty KD, Lotz JM, Shostak AW. Parasitology meets ecology on its own terms: Margolis et al. revisited. J Parasitol 1997; 83(4): $575-$ 583. http://dx.doi.org/10.2307/3284227. PMid:9267395

Cavichiolo F, Vargas L, Ribeiro RP, Moreira HL, Loures BRR, Maehana KPJA, et al. Efeito da suplementação de vitamina $C$ e vitamina $E$ na dieta, sobre a ocorrência de ectoparasitas, desempenho e sobrevivência em larvas de Tilápia do Nilo (Oreochromis niloticus, L.) durante a reversão sexual. Acta Sci 2002; 24(4): 943-948.

Choi S, Chung MH. A review on the relationship between Aloe vera components and their biologic effects. Seminars in Integrative Medicine 2003; 1(1): 53-62. http://dx.doi.org/10.1016/S1543-1150(03)00005-X

Coimbra JL, Soares ACF, Garrido MS, Sousa CS, Ribeiro FLB. Toxicidade de extratos vegetais a Scutellonema bradys. Pesquisa Agropecu Bras 2006; 41(7): 1209-1211. http://dx.doi.org/10.1590/S0100204X2006000700020.

Cruz C, Machado-Neto JG, Menezes ML. Toxicidade aguda do inseticida paration metílico e do biopesticida azadiractina de folhas de neem (Azadirachta indica) para alevino e juvenil de pacu (Piaractus mesopotamicus). Pesticidas: R. Ecotoxicol Meio Ambiente 2004; 14: 93-102.

Dotta G, Mourino JLP, Jatobá A, Morán REB, Pilati C, Martins ML. Acute inflammatory response in Nile tilapia fed Lactobacillus plantarum in the diet. Acta Sci Biol Sci 2011; 33(3): 239-246.

Douëllou L. Monogeneans of the genus Cichlidogyrus Paperna, 1960 (Dactylogyridae: Ancyrocephalinae) from cichlid fishes of Lake Kariba (Zimbabwe) with descriptions of five new species. Syst Parasitol 1993; 25(3): 159-186. http://dx.doi.org/10.1007/BF00007007.

Ergens R. Nine species of the genus Cichlidogyrus Paperna, 1960 (Monogenea: Ancyrocephalinae) from Egyptian fishes. Folia Parasitol 1981; 28: 205-214

Fujimoto RY, Helrik CC, Ramos FM. Controle alternativo de helmintos de Astyanax cf. zonatus utilizando fitoterapia com sementes de abóbora (Cucurbita maxima) e mamão (Carica papaya). Pesqui Vet Bras 2012; 32(1): 5-10. http://dx.doi.org/10.1590/S0100-736X2012000100002. 
Ghiraldelli L, Martins ML, Yamashita MM, Jerônimo GT. Ectoparasites influence on the haematological parameters of Nile tilapia and carp cultured in the State of Santa Catarina, South Brazil. J Fish Aquatic Sci 2006; 1(3): 270-276. http://dx.doi.org/10.3923/jfas.2006.270.276.

Ghisalberti EL. Propolis: A Review. Bee World 1979; 60(2): 59-84.

Goldenfarb PB, Bowyer FP, Hall E, Brosious E. Reproducibility in the hematology laboratory: the microhematocrit determination. Am J Clin Pathol 1971; 56(1): 35-39. PMid:5556212.

Imanishi K. Aloctin A, an active substance of Aloe arborescens Miller as an immunomodulator. Phytother Res 1993; 7(7): S20-S22. http://dx.doi. org/10.1002/ptr.2650070708.

Kim KH, Hwang YJ, Bai SC. Resistance to Vibrio alginolyticus in juvenile rockfish (Sebastes schlegeli) fed diets containing different doses of aloe. Aquaculture 1999; 180(1-2): 13-21. http://dx.doi.org/10.1016/S00448486(99)00143-X

Kobayashi H, Matsunaga K, Fujii M. PSK as a chemopreventive agent. Cancer Epidemiol Biomarkers Prev 1993; 2(3): 271-276. PMid:8318880.

Maeda YY, Takahama S, Yonekawa H. Four dominant loci for the vascular responses by the antitumor polysaccharide, lentinan. Immunogenetics 1998; 47(2): 159-165. http://dx.doi.org/10.1007/s002510050341. PMid:9396862

Marcucci MC. Propolis: chemical composition, biological properties and therapeutic activity. Apidologie 1995; 26(2): 83-99. http://dx.doi. org/10.1051/apido:19950202.

Martins ML, Pilarsky F, Onaka EM, Nomura DT, Fenerick J, Ribeiro $\mathrm{K}$, et al. Hematologia e resposta inflamatória aguda em Oreochromis niloticus (Osteichthyes: Cichlidae) submetida aos estímulos único e consecutivo de estresse de captura. B Inst Pesca 2004; 30(1): 71-80.

Martins ML, Romero NG. Efectos del parasitismo sobre el tejido branquial em peces cultivados: estúdio parasitologico e histopatologico. Rev Bras Zool 1996; 13(2): 489-500. http://dx.doi.org/10.1590/S010181751996000200017.

Matsuno T. Isolation and characterization of the tumoricidal substances from Brazilian propolis. Honeybee Sci 1992; 13: 49-54.

Moraes FR, Martins ML. Condiçóes predisponentes e principais enfermidades de teleósteos em piscicultura intensiva. In: Cyrino JE, Urbinati EC, Fracalossi DM, Castagnoli N. Tópicos especiais em piscicultura de água doce tropical intensiva. São Paulo: Tec Art; 2004. p. 343-383.

Murakami C, Cardoso FL, Mayworm MAS. Potencial fitotóxico de extratos foliares de Aloe arborescens Miller (Asphodelaceae) produzidos em diferentes épocas do ano. Acta Bot Bras 2009; 23(1): 111-116. http:// dx.doi.org/10.1590/S0102-33062009000100014.

Ni Y, Turner D, Yates KM, Tizard I. Isolation and characterization of structural components of Aloe vera L. leaf pulp. Int Immunopharmacol2004; 4(14): 1745-1755. http://dx.doi.org/10.1016/j.intimp.2004.07.006. PMid:15531291

Oda JMM, Fujita TC, Pitz AF, Amarante MK, Felipe I, Saridakis $\mathrm{HO}$, et al. Ação do extrato de própolis nas Leishmaniose. Semina: Ciênc Biol Saúde 2011; 32(1): 111-121.

Okyar A, Can A, Akev N, Baktir G, Sütlüpinar N. Effect of Aloe vera leaves on blood glucose level in type I and type II diabetic rat models. Phytother Res 2001; 15(2): 157-161. http://dx.doi.org/10.1002/ptr.719. PMid:11268118
Orsi RO, Funari SRC, Soares AMVC, Calvi SA, Oliveira SL, Sforcin JM, et al. Immunomodulatory action of propolis on macrophage activation. J Venom Anim Toxins 2000; 6(2): 205-219. http://dx.doi. org/10.1590/S0104-79302000000200006.

Orsi RO, Sforcin JM, Funari SR, Bankova V. Effects of Brazilian and Bulgarian propolis on bactericidal activity of macrophages against Salmonella typhimurium. Int Immunopharmacol 2005; 5(2): 359-368. http://dx.doi.org/10.1016/j.intimp.2004.10.003. PMid:15652765

Paez A, Michael Gebre G. Gonzalez ME, Tschaplinski TJ. Growth, soluble carbohydrates, and aloin concentration of Aloe vera plants exposed to three irradiance levels. Environ Exp Bot 2000; 44(2): 133-139. http:// dx.doi.org/10.1016/S0098-8472(00)00062-9. PMid:10996366

Paperna I, Thurston JP. Monogenetic trematodes collected from cichlid fish in Uganda; including the description of five new species of Cichlidogyrus. Rev Zool Bot Afr 1969; 79: 1-2.

Pariselle A, Euzet L. Gill parasites of the genus Cichlidogyrus Paperna, 1960 (Monogenea, Ancyrocephalidae) from Tilapia guineensis (Bleeker, 1862), with descriptions of six new species. Syst Parasitol 1995; 30(3): 187-198. http://dx.doi.org/10.1007/BF00010469.

Pavanelli GC, Eiras JC, Takemoto RM. Doenças de peixes:profilaxia, diagnóstico e tratamento. Maringá: UEM; 2008.

Pinheiro Filho R. Criação de abelhas. Cuiabá: SEBRAE; 1998.

Ranzani-Paiva MJ, Silva-Souza AT. Co-infestation of gills by different parasite groups in the mullet, Mugil platanus Günther, 1880 (Osteichthyes, Mugilidae): effects on relative condition factor. Braz J Biol 2004; 64(3B): 677-682. http://dx.doi.org/10.1590/S151969842004000400016. PMid:15620007

Rosenfeld G. Corante pancrômico para hematologia e citologia clínica. Nova combinação dos componentes do may-grunwald e do giemsa num só corante de emprego rápido. Mem Inst Butantan 1947; 20: 329-335.

Sakai R. Epidemiologic survey on lung cancer with respect to cigarette smoking and plant diet. Jpn J Cancer Res 1989; 80(6): 513-520. http:// dx.doi.org/10.1111/j.1349-7006.1989.tb01669.x. PMid:2503472

Salomão K, Dantas AP, Borba CM, Campos LC, Machado DG, Aquino Neto FR, et al. Chemical composition and microbicidal activity of extracts from Brazilian and Bulgarian propolis. Lett Appl Microbiol 2004; 38(2): 87-92. http://dx.doi.org/10.1111/j.1472-765X.2003.01458.x. PMid:14746537

Stevens N. O poder curativo da babosa: Aloe vera. São Paulo: Madra; 1999.

Tai-Nin Chow J, Williamson DA, Yates KM, Goux WJ. Chemical characterization of the immunomodulating polysaccharide of Aloe vera L. Carbohydr Res 2005; 340(6): 1131-1142. http://dx.doi.org/10.1016/j. carres.2005.02.016. PMid:15797128

Vega GA, Ampuero CN, Díaz NL, Lemus MR. Aloe vera (Aloe barbadensis Miller) as a component of functional foods. Rev Chil Nutr 2005; 32(3): 208-214. http://dx.doi.org/10.4067/S0717-75182005000300005.

Wichtl M. Herbal Drugs and Phytopharmaceuticals: a handbook for practice on a scientific basis. Stuttgart: Medpharma Scientific Publishers; 2004.

Xu D-H, Shoemaker CA, Martins ML, Pridgeon JW, Klesius PH. Enhanced susceptibility of channel catfish to the bacterium Edwardsiella ictaluri after parasitism by Ichthyophthirius multifliis. Vet Microbiol 2012; 158(1-2): 216-219. http://dx.doi.org/10.1016/j.vetmic.2012.02.007. PMid:22397934 